\title{
Aerobic Nitrogen Fixation in Aggregate-forming Cultures of the Nonheterocystous Cyanobacterium Microcoleus chthonoplastes
}

\author{
By G. MALIN*† AND H. W. PEARSON \\ Department of Botany, University of Liverpool, PO Box 147, Liverpool L69 3BX, UK
}

(Received 7 October 1987; revised 21 December 1987)

\begin{abstract}
Microcoleus chthonoplastes is a filamentous, nonheterocystous cyanobacterium which fixes gaseous nitrogen in axenic culture under aerobic conditions. Growth on agar plates reflects the benthic habit observed in the natural environment, and in liquid culture clumps or aggregates are produced. Scanning electron microscopy suggests that these aggregates are primarily the result of random movement of trichomes against one another. The aim of this study was to ascertain whether aggregation or any intracellular differentiation might be important in protection of the oxygen-labile nitrogenase in this species. Observations using light and transmission electron microscopy revealed no cellular or intracellular differentiation, and tetrazolium labelling experiments provided no evidence that a proportion of cells might act in a heterocyst-like fashion. The results presented suggest that nitrogen fixation in $\boldsymbol{M}$. chthonoplastes is unlikely to be enhanced in oxygen-deficient microsites formed as a result of aggregation.
\end{abstract}

\section{INTRODUCTION}

The nitrogenase complex is rapidly and irreversibly inactivated under aerobic conditions and therefore organisms which possess nitrogenase must exclude oxygen from the enzyme site. The need to protect nitrogenase from oxygen is particularly important in the oxygenic photosynthetic cyanobacteria since they must cope with endogenous oxygen production in addition to atmospheric oxygen. In this group of prokaryotes different degrees of oxygen tolerance of nitrogenase are evident.

Some cyanobacterial species utilize gaseous nitrogen only under anaerobic or microaerobic conditions. This capacity for nitrogen fixation would be masked under aerobic conditions but may be important ecologically because cyanobacteria are common in anoxic or reducing environments (Stewart, 1980). Some filamentous cyanobacteria differentiate specialized cells called heterocysts which are modified to permit the expression of nitrogenase activity under aerobic conditions. Oxygen diffusion into heterocysts is limited because of a specialized cell-wall structure (Walsby, 1985) and there is no photosynthetic oxygen evolution due to the absence of photosystem II (Tel-Or \& Stewart, 1977). Furthermore, traces of oxygen are utilized via respiration (Winkenbach \& Wolk, 1973), hydrogenase activity (Bothe et al., 1980) and oxygenscavenging enzymes (Henry et al., 1978).

There are also nonheterocystous cyanobacteria which fix nitrogen aerobically without specialized cells. Within this group the unicellular species Gloeothece has been extensively studied (see Gallon, 1980; Kallas et al., 1983) and the evidence suggests that nitrogenase activity and oxygenic photosynthesis coexist in a single cell type. Other nonheterocystous filamentous species are able to fix nitrogen under aerobic conditions; most frequent reports are for

† Present address: School of Environmental Sciences, University of East Anglia, Norwich NR4 7TJ, UK.

Abbreviations: TTC, 2,3,5-triphenyltetrazolium chloride. 
Oscillatoria (Trichodesmium) erythraea, which is an important planktonic component of nutrientpoor tropical and subtropical oceans. However, despite evidence that nitrogen fixation is associated with natural populations of $O$. erythraea, confirmation awaits the isolation and maintenance of axenic cultures. Aerobic nitrogenase activity has also been reported for benthic nonheterocystous cyanobacteria; Pearson et al. (1979) reported acetylene reduction by Microcoleus chthonoplastes, and this was later confirmed using axenic cultures (Pearson et al., 1981; R. Rippka, unpublished evidence cited by Kallas et al., 1983). Stal \& Krumbein (1981) also reported aerobic nitrogenase activity in a benthic Oscillatoria species.

It has been suggested that nitrogenase activity in the planktonic species $O$. erythraea may result from protection of the enzyme system in oxygen-deficient microsites within macroscopic aggregates or bundles of trichomes (Carpenter \& Price, 1976; Bryceson \& Fay, 1981), and Paerl (1985) emphasized the possible importance of aggregation in cyanobacteria as a means of establishing oxygen-depleted zones. In axenic culture, motile trichomes of $\boldsymbol{M}$. chthonoplastes form macroscopic bundles or aggregates. In this paper we present evidence that aerobic nitrogen fixation in this species is not dependent on the formation of these aggregates or the differentiation of specialized cells.

\section{METHODS}

Organism and growth. Microcoleus chthonoplastes (Thur.) Gom. was originally isolated from an intertidal mudflat (Pearson et al., 1979). It was subsequently isolated into clonal axenic culture by R. Rippka of the Pasteur Institute, Paris, France, using a single-filament transfer technique (Pasteur Culture Collection PCC 8002). Axenic cultures were maintained in a dilute artificial seawater medium of the following composition $\left(\mathrm{g} \mathrm{l}^{-1}\right): \mathrm{NaCl}(9 \cdot 33), \mathrm{KCl}$ (0.25), $\mathrm{MgSO}_{4} .7 \mathrm{H}_{2} \mathrm{O}(2.56), \mathrm{MgCl}_{2} .6 \mathrm{H}_{2} \mathrm{O}(1 \cdot 84), \mathrm{CaCl}_{2} .2 \mathrm{H}_{2} \mathrm{O}(0 \cdot 51), \mathrm{K}_{2} \mathrm{HPO}_{4}(0 \cdot 02), \mathrm{Na}_{2}$ EDTA (0.0008), ferric citrate $(0.0048)$, citric acid (0.0048). The trace element solution described by Allen (1968) was also added. The pH of the medium was controlled by adding $10 \mathrm{mM}$-HEPES and adjusting the $\mathrm{pH}$ to 8.0 prior to autoclaving at $121^{\circ} \mathrm{C}$ for $15 \mathrm{~min}$. Experimental material was grown in batch culture on an orbital shaker at 100 r.p.m., $28^{\circ} \mathrm{C}$ and a photon flux density of $65 \mu \mathrm{mol} \mathrm{m} \mathrm{m}^{-2} \mathrm{~s}^{-1}$ provided by deluxe natural fluorescent tubes. Due to the aggregated growth form of $\boldsymbol{M}$. chthonoplastes, uniformity of replicate cultures was achieved using a homogenized inoculum. Maximal acetylene reduction rates were observed in cultures after $7 \mathrm{~d}$ growth.

Biomass estimation. $M$. chthonoplastes samples were filtered onto $2.5 \mathrm{~cm}$ diameter glass-fibre filters and chlorophyll $a$ extracted in hot methanol. Samples containing distinct aggregates were macerated prior to extraction. After centrifuging at 2500 r.p.m. $(1000 \mathrm{~g})$ for $10-15$ min the absorbance of extracts was measured at 663 and $750 \mathrm{~nm}$ both before and after acidification. Since the ratios of unacidified to acidified readings were approximately 2, the formation of dicationic phaeophytin did not pose a problem (Marker et al., 1980). The chlorophyll content of each sample was calculated using a specific absorption coefficient for chlorophyll $a$ in methanol of $78 \mathrm{~cm}^{-1} \mathrm{~g}^{-1} 1$ and the equation described by Golterman et al. (1978). Alternatively dry weight was measured by filtering onto pre-dried and weighed glass-fibre filters and drying to constant weight at $60^{\circ} \mathrm{C}$. Samples were always analysed immediately.

Nitrogenase activity. This was estimated indirectly using the acetylene reduction technique as described by Stewart et al. (1971). Samples $(50 \mathrm{ml})$ of $M$. chthonoplastes were placed in $100 \mathrm{ml}$ Erlenmeyer flasks, the flasks were sealed with Suba-seal stoppers and acetylene was added to the gas phase to give a final concentration of $10 \%(\mathrm{v} / \mathrm{v})$. Samples were incubated at $28{ }^{\circ} \mathrm{C}$ and a photon flux density of $65 \mu \mathrm{mol} \mathrm{m} \mathrm{m}^{-2} \mathrm{~s}^{-1}$, and agitated at $100 \mathrm{r}$.p.m. on an orbital shaker. Background levels of ethylene were measured using samples of sterile medium plus acetylene, and cyanobacterial samples without acetylene, incubated under experimental conditions. Ethylene production was analysed using a Perkin-Elmer F11 gas chromatograph with flame ionization detector. Gases were separated on a $0.5 \mathrm{~m}$ length column, packed with 80-100 mesh Poropak $\mathrm{T}$, at an oven temperature of $60^{\circ} \mathrm{C}$. Ethylene concentrations were calculated with reference to calibrated standards using pure ethylene gas.

${ }^{14} \mathrm{CO}_{2}$ fixation. $\mathrm{NaH}^{14} \mathrm{CO}_{3}$ in a $\mathrm{NaHCO}_{3}$ carrier solution was added to each sample to give a concentration of $5 \mathrm{~mm}$ and a specific activity of $60 \mu \mathrm{Ci} \mathrm{mmol}^{-1}\left(2.22 \mathrm{MBq} \mathrm{mmol}^{-1}\right)$. Assay mixtures were incubated with shaking for $1 \mathrm{~h}$ and the reaction terminated by suction filtration and washing with $0 \cdot 1 \mathrm{M}-\mathrm{HCl}$ followed by distilled water. Radioactivity was determined using an LKB Wallac 1211 Mini-Beta liquid scintillation counter and results corrected for dark fixation and background radiation. Counting efficiency was $40 \%$.

Transmission electron microscopy. Aggregates of $M$. chthonoplastes were fixed for $4 \mathrm{~h}$ in $2 \%(\mathrm{v} / \mathrm{v})$ paraformaldehyde and $2.5 \%(\mathrm{v} / \mathrm{v})$ glutaraldehyde. The material was then washed in two changes of $0.1 \mathrm{M}$ cacodylate buffer (pH 7.2) using the method of Karnovsky (1965). Samples were post-fixed for $2-3 \mathrm{~h}$ in $1 \%$ (w/v) osmium tetroxide in $0.1 \mathrm{M}$-cacodylate buffer and then washed free of fixative in the same buffer for $30 \mathrm{~min}$. The samples were then dehydrated through a series of ethanol solutions. After infiltration with Spurr's resin (Spurr, 
1969) they were placed in flat embedding moulds and cured at $70^{\circ} \mathrm{C}$ for $16 \mathrm{~h}$. Sections $60-90 \mathrm{~nm}$ thick were cut using a glass knife, collected on 300 mesh copper grids, stained for $20 \mathrm{~min}$ in $0 \cdot 25 \%(\mathrm{w} / \mathrm{v})$ uranyl acetate and then washed in $50 \%(\mathrm{v} / \mathrm{v})$ ethanol followed by distilled water. Lead citrate was used for post-staining (Reynolds, 1963). Sections were examined using a Corinth 500 transmission electron microscope operating at $60 \mathrm{kV}, 125 \mu \mathrm{A}$.

Scanning electron microscopy. Aggregates of $M$. chthonoplastes were dehydrated through a series of ethanol solutions and then critical-point dried using liquid $\mathrm{CO}_{2}$. Samples were stuck onto aluminium specimen stubs and coated with gold/palladium (60/40) alloy in a vacuum coating unit. Individual aggregates were viewed using a Philips $501 \mathrm{~B}$ scanning electron microscope at an accelerating voltage of $7 \cdot 2 \mathrm{kV}$.

Tetrazolium reduction. Samples from active nitrogen-fixing cultures were treated with $0 \cdot 1 \%(\mathrm{w} / \mathrm{v}) 2,3,5$ triphenyltetrazolium chloride (TTC) then observed by light microscopy at frequent intervals for $2 \mathrm{~h}$.

\section{RESULTS}

The structure of cells, trichomes and aggregates

Traditional schemes for cyanobacterial identification placed $M$. chthonoplastes in the family Oscillatoriaceae on the basis that several trichomes were arranged in a common sheath. Although this filament arrangement was observed in field samples it was never seen in laboratory culture. Using the identification guidelines of Rippka et al. (1979), which were based on trichome structure and type cultures, $M$. chthonoplastes belongs in LPP group B. It has long, straight trichomes composed of a single cell type, there are no constrictions between adjacent cells and division occurs at right-angles to the long axis. Individual trichomes possess a distinct sheath and demonstrate gliding motility. Observations with the light microscope revealed no morphological differences between trichomes grown in the presence of nitrate or ammonia and those from nitrogen-fixing cultures. Similarly no obvious intracellular differentiation was seen.

Transmission electron microscopy was used to examine the subcellular organization of $M$. chthonoplastes. There were no obvious differences between samples cultured with and without combined nitrogen. Fig. 1 ( $a$ ) shows a transverse section of a typical cell of $M$. chthonoplastes with the thylakoids arranged in a distinct radial pattern, and Fig. $1(b)$ shows cells in longitudinal section, one of which has a thickened hood or calyptra. This particular end cell was likely to have been recently formed because it still retained subcellular structure, whereas older end cells are often dead or dying and lose their subcellular organization (Shukovsky \& Halfen, 1976). The electron micrographs of $\boldsymbol{M}$. chthonoplastes also reveal a very thick external envelope layer or sheath with a laminated appearance (Fig. $1 a, b$ ). Such extensive sheaths are not generally common in cyanobacteria, although Dermocarpa, a pleurocapsalean cyanobacterium, has a similar fibrous outer wall layer (Waterbury \& Stanier, 1978). It seems unlikely that the sheath could represent an efficient barrier to oxygen (analogous to the heterocyst envelope) since it would also limit the entry of nitrogen and the escape of photosynthetically produced oxygen. A sheathless mutant of the unicellular cyanobacterium Gloeothece retained nitrogenase activity (Kallas et al., 1983) which suggests that, in that species at least, the sheath plays no role in oxygen protection of nitrogenase.

In the natural environment $M$. chthonoplastes forms a cohesive mat, although sections of mat can break free and when covered with water these generally float to the surface. Mat-like growths also form on agar plates, with motile trichomes moving over the surface and penetrating into the gel. However, when replicate discs were taken from these artificial mats for experimentation, unacceptable variability in biomass and acetylene reduction was observed. Liquid culture was therefore more desirable for physiological experimentation. In static and shaken liquid batch culture $M$. chthonoplastes has a highly clumped or aggregated growth form. Because replicate static cultures demonstrated wider variability in growth and acetylene reducing ability, and since shaking cultures at 100 r.p.m. in the presence of air did not appear to decrease the rate of acetylene reduction, shaken batch culture was routinely used. Fig. 2(a) shows a typical shaken culture $7 \mathrm{~d}$ after inoculation with a homogenized suspension of $M$. chthonoplastes. Free filaments rarely occurred, although growth was occasionally seen on flask walls just above the level of the medium. Aggregates also occurred when the trichome density of the inoculum was reduced and in vigorously stirred, shaken or aerated cultures. The 

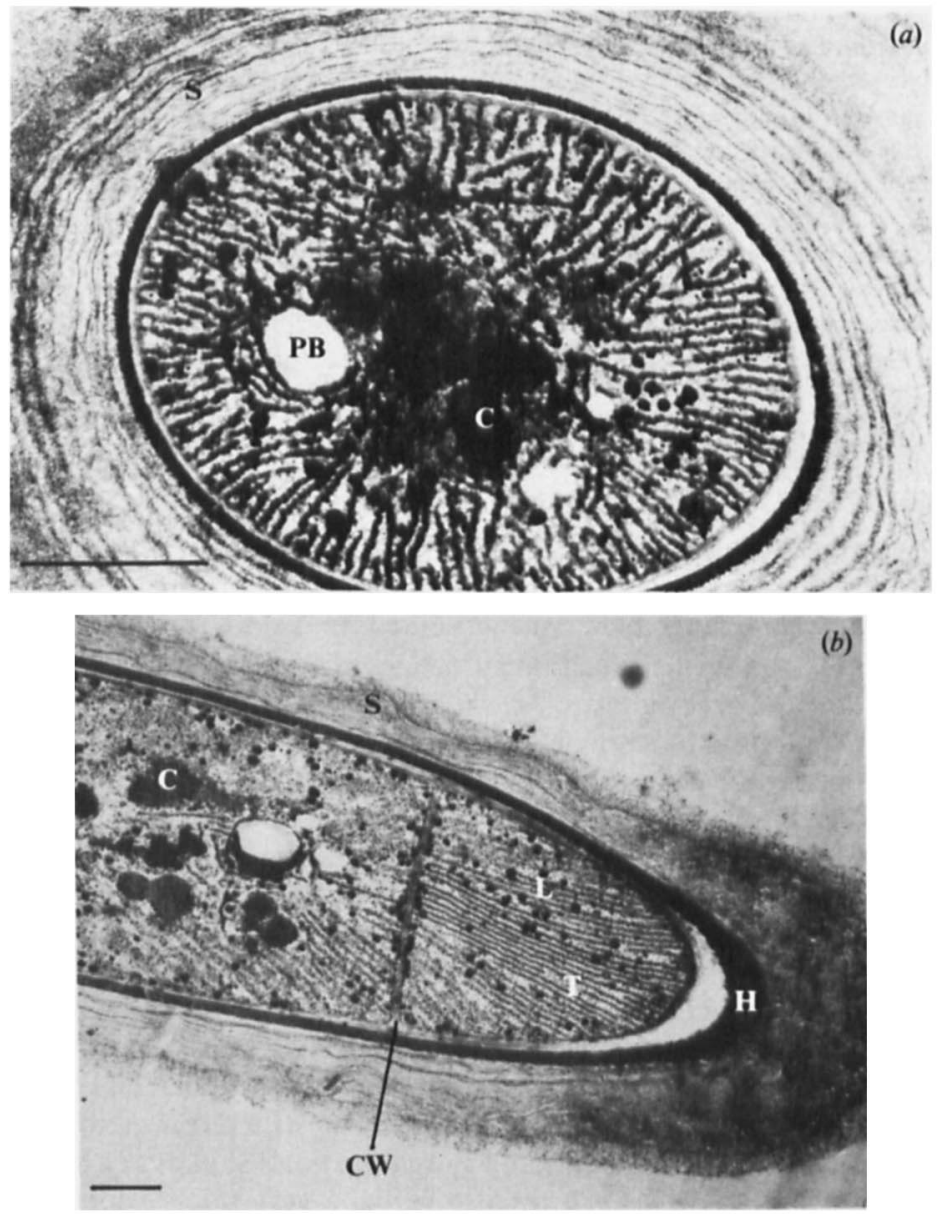

Fig. 1. Transverse (a) and longitudinal $(b)$ sections of $M$. chthonoplastes. Bars, $1 \mu \mathrm{m}$. C, carboxysome; $\mathrm{CW}$, cross wall; H, thickened hood or calyptra; L, Lipid globules; PB, polyphosphate bodies; $\mathrm{S}$, sheath; T, thylakoids.

(ต)

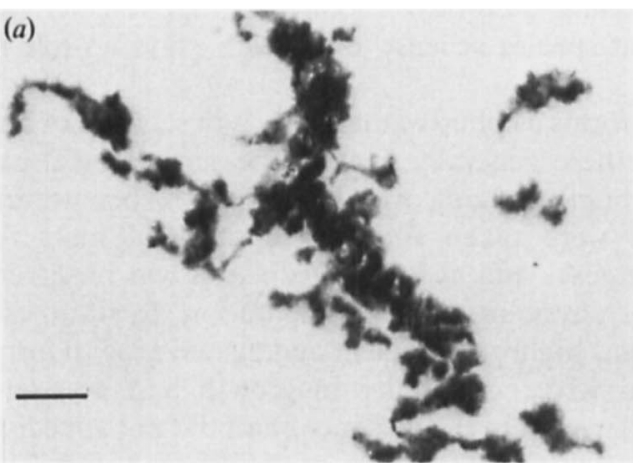

(b)

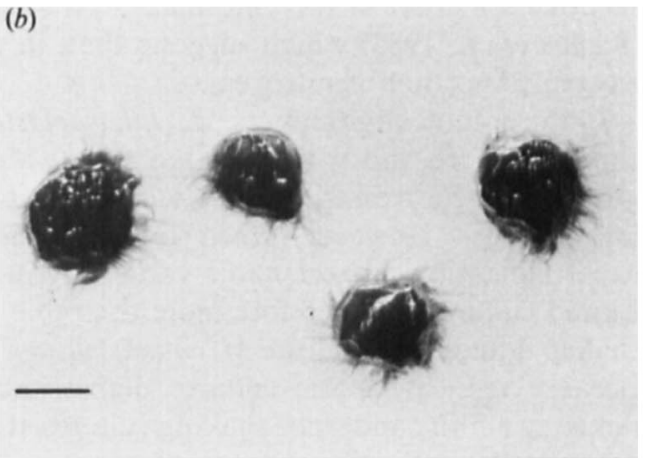

Fig. 2. (a) A typical 7-d-old culture of $M$. chthonoplastes grown in continuously shaken liquid medium, showing the aggregates produced despite inoculation with a homogeneous suspension. Bar, $0.5 \mathrm{~cm}$. (b) Large aggregated masses of $M$. chthonoplastes with streamers of roped trichomes extending into the medium, which developed when small clumps from a 7-d-old culture were periodically transferred to fresh medium over a 6 week period. Bar, $1 \mathrm{~cm}$. 

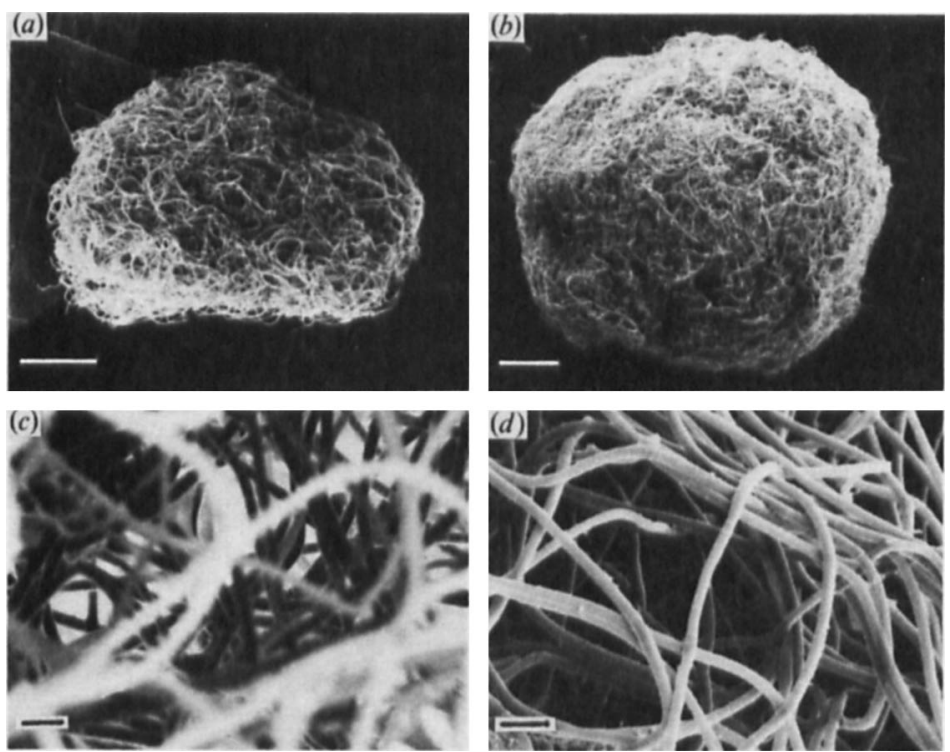

Fig. 3. (a) An aggregate from a 7-d-old culture of $M$. chthonoplastes. Bar, $400 \mu \mathrm{m}$. (b) An aggregate from a 14-d-old culture. Bar, $400 \mu \mathrm{m}$. (c) Detail of trichomes in a 7-d-old aggregate, which appears quite open. Bar, $25 \mu \mathrm{m}$. (d) The densely packed trichomes of the 14-d-old aggregate shown in $(b)$. Bar, $25 \mu \mathrm{m}$.

degree of aggregation was similar in cultures grown in the presence or the absence of combined nitrogen. With periodic transfer to fresh medium over a 6 week period the clumps of $M$. chthonoplastes developed into large aggregates with streamers of roped trichomes extending into the medium (Fig. $2 b$ ).

Scanning electron microscopy was used to examine the fine structure of aggregates of $M$. chthonoplastes. Fig. 3(a) shows the appearance of a small clump taken from a 7-d-old culture. It consisted of many randomly entwined trichomes. By careful positioning of the sample it was possible to look into and through the aggregate, which appeared quite open (Fig. 3c). An aggregate from a 14-d-old culture was larger and the trichomes were much more densely packed (Fig. $3 b, d$ ).

\section{Tetrazolium reduction}

The reducing capacity of individual cells of $M$. chthonoplastes and Anabaena cylindrica (Pasteur Culture Collection PCC 7122) from nitrogen-fixing cultures was compared using light microscopy to observe formazan crystal formation after treatment with TTC. After $20 \mathrm{~min}$ incubation a majority of the heterocysts in $A$. cylindrica preparations contained conspicuous formazan crystals (Fig. 4a), but these were not seen in vegetative cells until approximately 35 min after the addition of TTC. A similar result was noted for this species by Fay \& Kulasooriya (1972). In contrast, almost all the cells along the trichomes of $\boldsymbol{M}$. chthonoplastes showed simultaneous formazan deposition during a $20 \mathrm{~min}$ incubation period (Fig. $4 b$ ). With longer incubation periods larger crystal deposits built up but there was no change in the pattern of labelling. Furthermore, no differences in TTC reduction were found between trichomes from central and peripheral areas of aggregates. Very occasionally, short sections were observed in which no formazan crystals were deposited (Fig. 5). These areas were weakly pigmented, with cross-walls either absent or indistinct, and they lacked the granular appearance of normal cells when observed under oil immersion $(\times 1000)$. M. chthonoplastes trichomes divide by sacrificial cell breakage (Lamont, 1969), and the similarity in shape of terminal cells and cells bordering unlabelled areas suggested that they were dead or dying areas and thus unlikely to support significant dehydrogenase activity. 


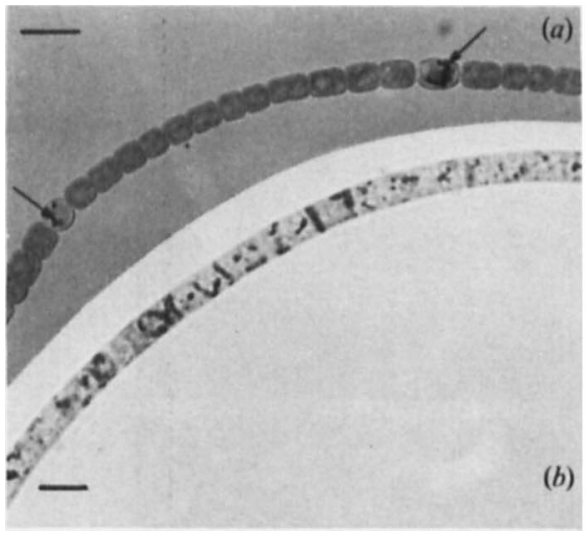

Fig. 4.

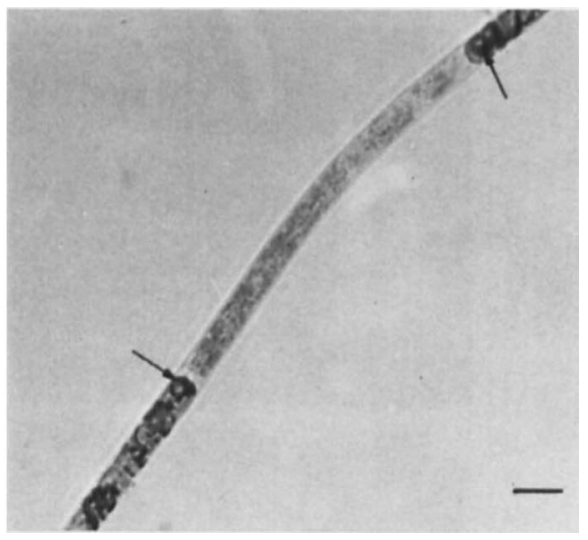

Fig. 5.

Fig. 4. (a) A filament of $A$. cylindrica after a 20 min exposure to TTC. The formazan crystals in the heterocysts are arrowed. Bar, $10 \mu \mathrm{m}$. (b) A trichome of $M$. chthonoplastes after a $20 \mathrm{~min}$ exposure to TTC, Bar, $10 \mu \mathrm{m}$.

Fig. 5. A region of dead or dying cells in a trichome of $M$. chthonoplastes where formazan crystals (arrowed in adjacent cells) were not deposited. Bar, $10 \mu \mathrm{m}$.

\section{Preparation of physiologically active homogeneous suspensions}

To ensure even inoculation of cultures, homogenized samples of $\boldsymbol{M}$. chthonoplastes were routinely used as an inoculum. This technique was investigated as a possible method for producing homogeneous material for short-term physiological experiments.

Three samples of $M$. chthonoplastes of identical wet mass were individually homogenized in a glass hand-held homogenizer. The samples were then incubated on an orbital shaker and nitrogenase activity monitored as acetylene reduction over a $24 \mathrm{~h}$ period (Fig. 6). After an initial period of $3 \mathrm{~h}$ during which no acetylene reduction was detected, there followed a period of recovery, and by $12 \mathrm{~h}$ after homogenization the increase in amount of acetylene reduced was approximately linear. Differences in the total quantity of ethylene produced by the three samples probably reflect slight differences in the degree of homogenization, but all the samples showed the same recovery pattern. In unshaken samples the recovery of nitrogenase activity was more variable. Recovery of acetylene reduction did not coincide with reaggregation of trichomes to the extent seen in untreated samples of $M$. chthonoplastes (Fig. 2a), although some reaggregation did occur.

Rates of acetylene reduction and carbon fixation were compared in identically homogenized samples $1 \mathrm{~h}$ and $12 \mathrm{~h}$ after treatment. After $1 \mathrm{~h}$ no acetylene reduction activity could be detected but the carbon fixation rate was $19568 \pm 2316$ c.p.m. $(\mathrm{mg} \text { dry weight) })^{-1}(n=10)$. After $12 \mathrm{~h}$ the rate of acetylene reduction had increased to $10.078 \pm 1.77 \mathrm{nmol} \mathrm{C}_{2} \mathrm{H}_{4}(\mu \mathrm{g} \mathrm{chl} a)^{-1} \mathrm{~h}^{-1}$ $(n=10)$ but, in contrast, there was little change in the carbon fixation rate $\left[21179 \pm 2754\right.$ c.p.m. (mg dry weight) $\left.{ }^{-1} ; n=10\right]$. There was no recovery of acetylene reduction in dark-incubated samples or when the protein synthesis inhibitors chloramphenicol or rifampicin $\left(50 \mu \mathrm{g} \mathrm{ml}^{-1}\right)$ were added. In a further experiment ten identical cultures were set up from a homogenized inoculum and after $7 \mathrm{~d}$ growth five of these were carefully homogenized. Following a $12 \mathrm{~h}$ recovery period the homogenized samples showed an acetylene reduction rate of $5.140 \pm 0.486 \mathrm{nmol} \mathrm{C}_{2} \mathrm{H}_{4}(\mu \mathrm{g} \mathrm{chl} a)^{-1} \mathrm{~h}^{-1}$ compared to $2.525 \pm 0.341 \mathrm{nmol}^{2} \mathrm{C}_{2} \mathrm{H}_{4}$ $(\mu \mathrm{g} \mathrm{chl} a)^{-1} \mathrm{~h}^{-1}$ for the aggregated control samples. If nitrogenase activity in $M$. chthonoplastes was enhanced by the presence of oxygen-deficient microsites produced as a result of aggregation we might have expected the homogenized samples to show a lower rate of acetylene reduction.

It should be mentioned that it was difficult to standardize the extent of homogenization in different batches of material, so that although good replication was obtained within experiments, similar experiments performed at different times often showed considerable 


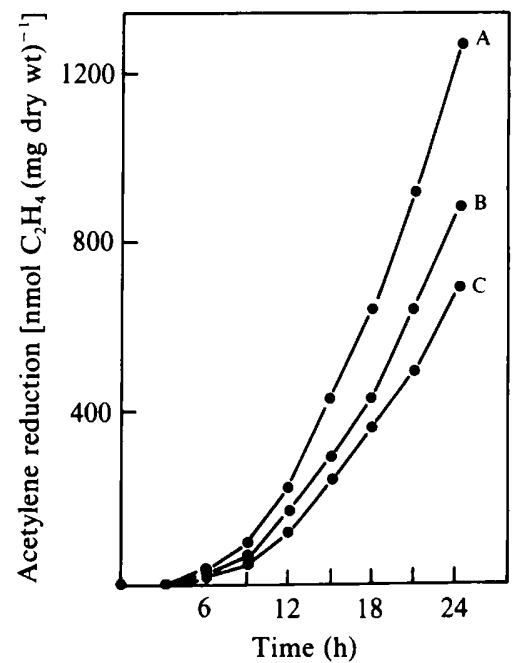

Fig. 6. Time course of acetylene reduction following homogenization in a glass hand-held homogenizer at $t=0$. Samples A, B and C were from the same 7-d-old culture and were of the same size, but they were homogenized separately.

variation in the rate of acetylene reduction and subsequent growth. Thus when direct quantitative comparison between different experimental treatments was required, material had to be obtained from the same homogenized inoculum.

\section{DISCUSSION}

The nonheterocystous cyanobacterium $M$. chthonoplastes forms aggregates or clumps in axenic liquid cultures grown in the presence or the absence of combined nitrogen. The aggregates appeared unstructured when observed by scanning electron microscopy, and light and transmission electron microscopy revealed no differentiation in trichomes or cells which might account for aerobic nitrogenase activity. When cells from central and peripheral areas of aggregates were treated with tetrazolium salts, formazan crystals were seen in a majority of cells at roughly the same time, with the rare exception of areas of trichome division. A direct nitrogenase labelling method is required to solve the problem of enzyme location in nonheterocystous cyanobacteria. The immunoferritin labelling method of Murray \& Benemann (1980) or the monoclonal antibody technique developed by Baker et al. (1984) might prove suitable for such a survey.

The clumping characteristic of $M$. chthonoplastes makes direct physiological experimentation difficult, so our approach was to homogenize the aggregates. Immediately after homogenization, nitrogenase activity was lost but subsequently it recovered before the trichomes had reaggregated to their former extent. Furthermore, following recovery, homogenized samples showed substantially higher rates of acetylene reduction than untreated controls. It therefore seems unlikely that aggregation leads to the production of nitrogenase-protecting oxygendeficient microsites. It seems more likely that the aggregation in cultures of this species reflects the original isolation of $\boldsymbol{M}$. chthonoplastes from a benthic habitat and its gliding motility, rather than a response to nitrogen fixation and protection of the nitrogenase enzyme from oxygen damage. We believe that growth in liquid culture and homogenization to decrease the degree of aggregation represents the best approach to physiological experimentation with $M$. chthonoplastes.

The contribution made to the nitrogen cycle by nonheterocystous cyanobacteria is unknown but they may be most important in environments where heterocystous species are excluded due to the presence of free sulphide (Howsley, 1980). Pearson \& Howsley (1980) showed that 
sulphide stimulated nitrogen fixation in Plectonema boryanum in a concentration-dependent way by intracellular chemical reduction of photosynthetically produced oxygen or inhibition of oxygenic photosynthesis. In laboratory gradient systems motile cyanobacteria demonstrate a number of tactic responses including chemotaxis (Malin \& Walsby, 1985). In the natural environment filaments of motile species such as $M$. chthonoplastes could perhaps retreat into the more reduced sediments below the surface of a cyanobacterial mat to prevent excessive oxygen damage to nitrogenase.

We thank Tony Tollit for photography, and Kees Veltkamp and Jim Smith for assistance with scanning and transmission microscopy, respectively. This work was done while G.M. was in receipt of a postgraduate studentship from the SERC.

\section{REFERENCES}

ALLEN, M. M. (1968). Simple conditions for growth of unicellular blue-green algae on plates. Journal of Phycology 4, 1-4.

BAKER, D., Lending, C. \& DeAN, D. (1984). Localisation of nitrogenase using monoclonal antibodies. In Advances in Nitrogen Fixation Research, p. 249. Edited by C. Veeger and W. E. Newton. The Hague: Martinus Nijhoff/Dr W. Junk.

Bothe, H., Neuer, G., Kalbe, I. \& Eisbrenner, G. (1980). Electron donors and hydrogenase in nitrogen-fixing microorganisms. In Nitrogen Fixation, pp. 83-112. Edited by W. D. P. Stewart \& J. R. Gallon. London: Academic Press.

BRYCESON, I. \& FAY, P. (1981). Nitrogen fixation in Oscillatoria (Trichodesmium) erythraea in relation to bundle formation and trichoma differentiation. Marine Biology 61, 159-166.

Carpenter, E. J. \& Price, C. C. (1976). Marine Oscillatoria (Trichodesmium): explanation for aerobic nitrogen fixation without heterocysts. Science 191, 1278-1280.

Fay, P. \& Kulasooriya, S. A. (1972). Tetrazolium reduction and nitrogenase activity in heterocystous blue-green algae. Archives of Microbiology 87, 341352.

GALLON, J. R. (1980). Nitrogen fixation by photoautotrophs. In Nitrogen Fixation, pp. 197-238. Edited by W. D. P. Stewart \& J. R. Gallon. London: Academic Press.

Golterman, H. L., Clymo, R. S. \& Ohnstad, M. A. M. (1978). Methods for Physical and Chemical Analysis of Fresh Waters, 2nd edn. Oxford: Blackwell Scientific Publications.

Henry, L. E. A., Gogotov, I. N. \& Hall, D. O. (1978). Superoxide dismutase and catalase in the protection of the proton-donating system of nitrogen fixation in the blue-green alga Anabaena cylindrica. Biochemical Journal 174, 373-377.

HowsLEY, R. (1980). Aspects of the physiology and ecology of cyanobacteria in relation to hydrogen sulphide. PhD thesis, University of Liverpool.

Kallas, T., RIPPKa, R., Coursin, T., Rebiere, M.-C., Tandeau de Marsac, N. \& Cohen-Bazire, G. (1983). Aerobic nitrogen fixation by nonheterocystous cyanobacteria. In Photosynthetic Prokaryotes: Cell Differentiation and Function, pp. 281-314. Edited by G. C. Papageorgiou \& L. Packer. Amsterdam: Elsevier.
KARNOVSKY, M. J. (1965). A formaldehyde-glutaraldehyde fixative of high osmolality for use in electron microscopy. Journal of Cell Biology 27, 137A.

LAMONT, H. C. (1969). Sacrificial cell death and trichome breakage in an oscillatoriacean blue-green alga: the role of murein. Archives of Microbiology 69, 237-259.

Malin, G. \& Walsby, A. E. (1985). Chemotaxis of a cyanobacterium on concentration gradients of carbon dioxide, bicarbonate and oxygen. Journal of General Microbiology 131, 2643-2652.

Marker, A. F. H., Nusch, E. A., RaI, H. \& ReimanN, B. (1980). The measurement of photosynthetic pigments in freshwaters and standardisation of methods: conclusions and recommendations. Archiv für Hydrobiologie Beihefte - Ergebnisse der Limnologie 14, 91-106.

Murray, M. A. \& BenemanN, J. R. (1980). Localisation of nitrogenase in a heterocystous blue-green alga by immunoferritin labelling. Journal of Phycology (Supplement) 16, Abstract 109.

PAERL, H. W. (1985). Microzone formation: its role in the enhancement of aquatic $\mathrm{N}_{2}$ fixation. Limnology and Oceanography 30, 1246-1252.

Pearson, H. W. \& Howsley, R. (1980). Concomitant photoautotrophic growth and nitrogenase activity by the cyanobacterium Plectonema boryanum in continuous culture. Nature, London 288, 263-265.

Pearson, H. W., Howsley, R., Kueldsen, C. K. \& W ALSBY, A. E. (1979). Aerobic nitrogenase activity associated with a non-heterocystous filamentous cyanobacterium. FEMS Microbiology Letters 5, 163167.

Pearson, H. W., Malin, G. \& Howsley, R. (1981). Physiological studies on in vivo nitrogenase activity by axenic cultures of the blue-green alga Microcoleus chthonoplastes. (Abstract). British Phycological Journal 16, 139.

REYNOLDS, E. S. (1963). The use of lead citrate at high $\mathrm{pH}$ as an electron-opaque stain in electron microscopy. Journal of Cell Biology 17, 208-212.

RiPPKA, R., Deruelles, J., Waterbury, J. B., Herdman, M. \& Stanier, R. Y. (1979). Generic assignments, strain histories and properties of pure cultures of cyanobacteria. Journal of General Microbiology 111, 1-61.

ShUKovSKy, E. S. \& HalfEN, L. N. (1976). Cellular differentiation of terminal regions of Oscillatoria 
princeps (Cyanophyceae). Journal of Phycology 12, TEL-OR, E. \& STEWART, W. D. P. (1977). Photosyn336-342.

SPURR, A. R. (1969). A low viscosity epoxy resin embedding medium for electron microscopy. Journal of Ultrastructure Research 26, 31-43.

Stal, L. J. \& Krumbein, W. E. (1981). Aerobic nitrogen fixation in pure cultures of a benthic Oscillatoria (cyanobacteria). FEMS Microbiology Letters 11, 295-298.

STEWART, W. D. P. (1980). Some aspects of structure and functions in $\mathrm{N}_{2}$-fixing cyanobacteria. Annual Review of Microbiology 34, 497-536.

Stewart, W. D. P., Mague, T., Fitzgerald, G. P. \& BurRIS, R. H. (1971). Nitrogenase activity in Wisconsin lakes of differing degrees of eutrophication. New Phytologist 70, 497-509. thetic components and activities of nitrogen fixing isolated heterocysts. Proceedings of the Royal Society B198, 61-86.

WALSBY, A. E. (1985). The permeability of heterocysts to the gases nitrogen and oxygen. Proceedings of the Royal Society B226, 345-366.

WATERBURY, J. B. \& STANIER, R. Y. (1978). Patterns of growth and development in pleurocapsalean cyanobacteria. Microbiological Reviews 42, 2-44.

Winkenbach, F. \& Wolk, C. P. (1973). Activities of enzymes of the oxidative and reductive pentose phosphate pathways in heterocysts of a blue-green alga. Plant Physiology 52, 480-483. 